\title{
Peningkatan Kapasitas Produksi Usaha Rumah Tangga Keripik dan Kue Bawang Bengkong Palapa
}

\author{
Nofriani Fajrah*1, Handra Tipa ${ }^{2}$, Elva Susanti ${ }^{3}$, Ahmad Ardianto ${ }^{4}$, Anugrah \\ Setiawan Harefa ${ }^{5}$ \\ ${ }^{1,3,4}$ Program Studi Teknik Industri, Fakultas Teknik dan Komputer, Universitas Putera \\ Batam, \\ Jl. R. Soeprapto, Muka Kuning, Batam \\ ${ }^{2,5}$ Program Studi Akuntansi, Fakultas Sosial dan Humaniora, Universitas Putera Batam, \\ J1. R. Soeprapto, Muka Kuning, Batam \\ e-mail: ${ }^{* 1}$ fajrahnofriani@ gmail.com, ${ }^{2}$ handratipa@gmail.com, \\ ${ }^{3}$ srikandhi_elva@yahoo.co.id, ${ }^{4}$ ahmadardianto53@gmail.com, \\ ${ }^{5}$ Anugrahhrf96@gmail.com
}

\section{Informasi Artikel \\ Diterima Redaksi: $x x x$ \\ Revisi Akhir: $x x x$ \\ Diterbitkan Online: $x x x$}

\section{Kata Kunci}

Keripik, Kue Bawang, Peramalan Produksi, Rencana Produksi, Usaha Rumah Tangga

Korespondensi :

fajrahnofriani@gmail.com No. HP: 0822-8559-5792

\section{Abstract} Para Ibu Rumah Tangga (IRT) Bengkong Palapa ikut serta dalam membantu memenuhi kebutuhaan biaya rumah tangga. Hal ini dikarenakan keluarga di Perumahan Bengkong Palapa bergantung kepada perolehan pendapatan dari gaji bulanan kepala keluarga yang bekerja yaitu inovasi membangun usaha rumah tangga. Inovasi seeprti menjual makanan ringan seperti keripik dan kue bawang. Tujuan kegiatan pengabdian ini adalah meningkatkan kapasitas produksi yaitu dengan membina merencanakan produksi dengan membuat peramalan permintaan produk sehingga dapat dibuat rencana produksi. Metode pengabdian dibagi menjadi dua yaitu metode pelaksanaan kegiatan (penyampaian materi, praktek langsung (learning by doing) dan pendampingan) dan metode topik pengabdian (metode peramalan permintaan produk dan perencanaan produksi). Berdasarkan hasil kegiatan pengabdian ini, diperoleh bahwa Mitra Keripik dan Mitra Kue Bawang masih menggunakan metode perkiraan dan pengalaman hasil penjualan dalam menentukan rencana jumlah produksi. Selain itu, mitra keripik dan mitra kue bawang sudah mulai mencoba menerapkan perencanaan produksi dengan konsep peramalan. Berdasarkan hasil implementasi tersebut, mitra keripik dan mitra kue bawang dapat meminimasi pemborosan overproduction dan menjadwalkan produksi secara efektif dan efisien. 


\section{PENDAHULUAN}

Kesulitas perekonomian smayarakat juga dialami oleh keluarga di Peurmahan Bengkong Palapa. Perumahan Bengkong Palapa merupakan salah satu komplek perumahan yang terletak di Kelurahan Tanjung Buntung. Rata-rata perekonomian keluarga di Perumahan Bengkong Palapa bergantung kepada sektor industri. Hal ini dikarenakan sebagian besar dari kepala keluarga di Perumahan Bengkong Palapa bekerja di sekrot industri manufaktur. Kondisi tersebut menunjukkan bahwa tingkat perekonomian keluarga berbasis kepada perolehan pendapatan dari gaji bulanan kepala keluarga yang bekerja di sektor industri manufaktur.

Namun, kondisi sektor industri yang semakin menurun, juga memberikan dampak kepada tingkat perekonomian 85 kepala keluarga di Perumahaan Bengkong Palapa. Beberapa diantaranya masih bertahan dengan gaji bulanan kepala keluarga yang bekerja di sektor industri manufaktur, namun beberapa diantara lainnya mengalami penurunan tingkat kesejahteraan.

Berdasarkan kondisi tersebut, memotivasi ibu-ibu rumah tangga di Perumahan Bengkong Palapa untuk ikut membantu perekonomian keluarga. Motivasi untuk membantu perekonomian keluarga dengan menciptakan inovasi dalam membangun usaha rumah tangga oleh ibu-ibu rumah tangga di Perumahan Bengkong Palapa. Usaha rumah tangga dijalankan berdasarkan pengetahuan dan pengalaman ibu-ibu rumah tangga.

Usaha rumah tangga sebagai salah satu bagian kecil dalam menunjang peningkatan perekonomian suatu daerah. Menurut [1], menyatakan bahwa usaha rumah tangga menempati posisi yang cukup strategis karena menyerap $88 \%$ tenaga kerja. Selain itu, [1] menjelaskan pada kondisi sosial ekonomi yang menurun saat ini, maka peran dari usaha rumah tangga sangat signifikan dalam memberikan kontribusi stabilitas perekonomian. Usaha rumah tangga merupakan penggerak stabilitas perekonomian yang disebut dengan ekonomi rakyat.

Adapun usaha rumah tangga yang saat ini masih dijalankan oleh ibu rumah tangga adalah usaha rumah tangga keripik dan kue bawang. Keripik merupakan salah satu panganan yang digemari oleh masyarakat luas. Keripik sebagai cemilan ringan yang dapat dikonsumsi oleh masyarakat dari berbagai kalangan usia dan gender. Keripik dapat disantap sebagai makanan ringan atau makanan pendamping seperti mie instan, sate, lontong dan lainnya.

Keripik yang diproduksi biasanya berbahan dasar ubi kayu dan beberapa bumbu tradisional sesuai resep masingmasing produsen. Keripik memiliki banyak jenis yaitu keripik pedas, keripik pedas manis, keripik gurih dan keripik rasa original. Keripik dijual dalam bentuk beberapa jenis ukuran kemasan, yaitu ada ukuran Rp 1000, ukuran Rp 5000 dan ukuran Rp 15.000. Keripik ini dijual pada beberapa tempat seperti di warung, dikantin sekolah, kantin kampus atau kantin perkantoran maupun dijual di toko.

Selain keripik, ada juga cemilan lain yang dibahas dalam kegiatan pengabdian ini yaitu kue bawang. Kue Bawang merupakan salah satu panganan yang juga digemari oleh masyarakat luas. Kue Bawang sebagai cemilan ringan yang dapat dikonsumsi oleh masyarakat dari berbagai kalangan usia dan gender. Kue Bawang dapat disantap sebagai makanan ringan atau makanan pendamping seperti mie instan, sate, lontong dan lainnya. 
Kue Bawang yang diproduksi biasanya berbahan dasar tepung, telur, mentega, dan beberapa bumbu tradisional sesuai resep masing-masing produsen. Kue Bawang memiliki banyak jenis yaitu kue bawang rasa pedas, kue bawang pedas manis, kue bawang gurih dan kue bawang rasa original. Kue bawang dijual dalam bentuk beberapa jenis ukuran kemasan, yaitu ada ukuran Rp 1000, ukuran Rp 5000 dan ukuran Rp 15.000. Kue bawang ini dijual pada beberapa tempat seperti di warung, dikantin sekolah, kantin kampus atau kantin perkantoran maupun dijual di toko.

Namun, kondisi yang ditemukan adalah usaha rumah tangga keripik dan kue bawang masih belum produktif. Hal ini disebabkan oleh keirpik dan kue bawang yang diproduksi selalu sama setiap periode waktu. Hal ini mengakibatkan, hasil penjualan menjadi tidak maksimal, karena apabila produk tidak laku, maka menjadi kerugian yang ditanggung oleh usaha rumah tangga tersebut. Oleh karena itu, perlu adanya kegiatan pengabdian ini, agar usaha rumah tangga keripik dan kue bawang di Perumahan Bengkong Palapa menjadi lebih produktif.

\subsection{Profil Mitra}

\section{Profil Mitra URT Keripik}

Mitra URT Keripik merupakan salah satu usaha rumah tangga yang ada di Perumahan Bengkong Palapa. URT Keripik ini dikelola oleh ibu Hafsah sejak tahun 2016. URT Keripik ini masih dikelola secara konvensional, karena Ibu Hafsah sama sekali tidak memiliki pengetahuan mengenai sistem produksi yang efektif dan efisien.

Ibu Hafsah dalam menjalankan URT Keripik hanya berdasarkan pengalaman menitipkan keripik di warung dan di kantin atau tempat makan saja dengan tidak memperhatikan hasil produk yang terjual dari periode ke periode berikutnya. Berdasarkan kondisi tersebut, ibu hafsah tidak memiliki rencana produksi yang efektif dan efisien sehingga hanya memproduksi keripik dengan jumlah yang sama pada setiap periodenya.

Berdasarkan kondisi tersebut, URT Keripik ibu Hafsah hanya memperoleh keuntungan yang rendah. Hal ini dikarenakan, setiap keripik yang tidak laku dijual, dikembalikan dan yang dibayarkan oleh toko atau warung hanya sebanyak jumlah produk yang terjual saja. Selain itu, hasil penjualan harus digunakan lagi sebagai modal dalam membeli bahan baku untuk produksi keripik di periode berikutnya.

\section{Profil Mitra URT Kue Bawang}

Mitra URT Kue Bawang merupakan salah satu usaha rumah tangga yang ada di Perumahan Bengkong Palapa. URT Kue Bawang ini dikelola oleh ibu As sejak tahun 2015. URT Kue Bawang ini masih dikelola secara konvensional, karena Ibu As sama sekali tidak memiliki pengetahuan mengenai sistem produksi yang efektif dan efisien.

Ibu As dalam menjalankan URT Kue Bawang hanya berdasarkan pengalaman menitipkan keripik di warung dan di kantin atau tempat makan saja dengan tidak memperhatikan hasil produk yang terjual dari periode ke periode berikutnya. Berdasarkan kondisi tersebut, ibu As tidak memiliki rencana produksi yang efektif dan efisien sehingga hanya memproduksi kue bawang dengan jumlah yang sama pada setiap periodenya.

Berdasarkan kondisi tersebut, usaha kue bawang ibu As memperoleh keuntungan yang rendah. Hal ini dikarenakan, setiap kue bawang yang 
tidak laku dijual, dikembalikan dan yang dibayarkan oleh toko atau warung hanya hanya sebanyak jumlah produk yang terjual saja. Selain itu, hasil penjualan harus digunakan lagi sebagai modal dalam membeli bahan baku untuk produksi kue bawang di periode berikutnya.

\subsection{Identifikasi Permasalahan}

Berdasarkan hasil pemaparan latar belakang permasalahan dan profil dari kedua mitra, maka dapat diidentifikasi permasalahan yang akan diselesaikan dengan kegiatan pengabdian ini. Permasalahan yang dihadapi di URT Keripik dan Kue Bawang adalah sebagai berikut:

a. Jumlah produksi tidak sesuai dengan jumlah permintaan dari penjualan, sehingga mengakibatkan persentase produk tidak laku terjual menjadi tidak terkendali.

b. Proses produksi tidak terjadwal dengan baik dikarenakan dalam proses produksi hanya berdasarkan pemesanan yang ada, sedangkan untuk pemenuhan jumlah permintaan pada tempat penitipan selalu sama setiap periode waktu.

c. Tingkat produksi rendah dikarenakan tidak mempertimbangkan permintaan, kebutuhan bahan baku dan hasil penjualan.

d. Pemborosan dalam bentuk overproduction dikarenakan ditemukan sejumlah produk yang tidak terjual (tersisa atau tidak laku maka dikembalikan) yang diletakkan di tempat penitipan menjadi kerugian yang ditanggung oleh mitra.

e. Keuntungan bersih (netto profit) dari hasil penjualan sangat rendah dikarenakan hasil dari penjualan (revenue) digunakan sebagai modal untuk membeli bahan baku untuk proses produksi berikutnya.

Oleh karena itu, perlu adanya kegiatan pengabdian ini dilakukan guna menciptakan dan membangun URT Keripik dan Kue Bawang yang dapat merencanakan output produksi sehingga kapasitas produksi menjadi meningkat. Dengan adanya kegiatan pengabdian ini URT Keripik dan Kue Bawang dapat meningkatkan produktivitas. Selain itu, juga diharapkan dapat meningkatkan pertumbuhan margin keuntungan agar dapat meningkatkan kesejahteraan baik bagi mitra maupun bagi lingkungan sekitar masyarakat. Selain itu, diharapkan URT Keripik dan Kue Bawang mampu bersaing dengan industri kecil menengah hingga industri makanan skala besar. Berdasarkan pencapaian tersebut, maka URT Keripik dan Kue Bawang telah menjadi agen peningkatan dan pertumbuhan kesejahteraan bangsa secara mandiri.

\section{METODE KEGIATAN}

Metode pengabdian dirancang sesuai dengan tujuan dari aktivitas kegiatan pengabdian ini yaitu meningkatkan kapasitas produksi URT Keripik dan Kue Bawang Bengkong Palapa. Tujuan pengabdian : Peningkatan kapasitas produksi yaitu dengan pembinaan merencanakan produksi. Pembinaan perencanaan produksi berdasarkan hasil peramalan permintaan produk.

Berdasarkan pelaksanaan kegiatan pengabdian tersebut terdapat beberapa sasaran strategis yang akan dicapai yaitu: 
a. Bahan baku yang digunakan atau yang dibeli sesuai dengan jumlah permintaan produk

b. Jumlah produk yang diproduksi sesuai dengan permintaan produk

c. Menghilangkan pemborosan yaitu overproduction

d. Dapat memenuhi permintaan produk dari segi pesanan (demand-to-order) maupun permintaan produk untuk dijual secara langsung pada tempattempat pemasaran (make-to-stock)

Metode pelaksanaan kegiatan pengabdian dibagi menjadi dua:

a. Penyampaian materi pengabdian

b. Praktek langsung (learning by doing) dan pendampingan

Adapun pelaksanaan kegiatan pengabdian ini dilaksanakan dalam beberapa tahapan yaitu sebagai berikut:

a. Tahapan Persiapan

Pada tahapan ini dilakukan selama satu bulan. Adapun kegiatan yang dilakukan meliputi :

1) Penyusunan materi kegiatan pengabdian

2) Penyusunan tim pengabdi yang terdiri atas moderator, narasumber dan notulen kegiatan

3) Penyusunan indikator evaluasi kegiatan

4) Kunjungan Awal dalam menyampaikan maksud dan tujuan dari kegiatan

b. Tahapan Pelaksanaan Kegiatan Penyampaian Materi
Pada tahapan ini dilakukan selama dua minggu. Adapun kegiatan yang dilakukan meliputi :

1) Penyampaian materi tentang topik rencana produksi

2) Penyampaian materi tentang topik peramalan produksi

Kegiatan dilakukan selama dua kali dalam 2 bulan dari bulan November 2018 - Januari 2019.

c. Tahapan Pelaksanaan Pendampingan Pada tahapan ini dilakukan selama dua minggu. Adapun kegiatan yang dilakukan meliputi :

1) Praktek langsung (learning by doing) dan pendampingan implementasi rencana produksi

2) Praktek langsung (learning by doing) dan pendampingan implementasi peramalan produksi

Kegiatan dilakukan selama dua kali dalam 2 bulan dari bulan Desember 2018 - Januari 2019.

d. Tahapan Evaluasi Kegiatan

Pada tahapan ini dilakukan selama satu minggu. Adapun kegiatan yang dilakukan meliputi :

1) Evaluasi implementasi rencana produksi

2) Evaluasi implementasi peramalan produksi

Kegiatan dilakukan selama satu kali dalam 1 bulan pada bulan Februari 2019. 


\section{HASIL DAN PEMBAHASAN}

Berdasarkan hasil kegiatan pengabdian, maka dapat diketahui bagaimana perkembangan kedua mitra dalam meningkatkan kapasitas produksi. Tabel 1 menunjukkan hasil pencapaian kedua mitra setelah dilakukan kegiatan pengabdian.

Selama kegiatan pengabdian berlangsung, mitra sangat kooperatif dan memiliki semangat yang tinggi untuk meningkatkan pengetahuan dalam meningkatkan kapasitas produksi. Hal ini ditunjukkan dengan pertanyaan-pertanyan dari kedua mitra mengenai topik materi pengabdian. Kegiatan pengabdian berjalan dengan lancar sesuai dengan rencana kegiatan yang telah disusun.

Berdasarkan permasalahan yang dihadapi oleh kedua mitra yaitu kapasitas produksi yang rendah sehingga mengakibatkan keuntungan yang diperoleh juga rendah. Maka dilakukan kegiatan pengabdian ini, yaitu pemberian materi bagaimana membuat rencana produksi yang efektif dan efisien.

Rencana produksi merupakan salah satu aktivitas sebelum dilaksanakan proses produksi pada suatu industri. Hal tersebut juga berlaku untuk industri kecil menengah bahkan untuk unit usaha rumah tangga sekalipun. Rencana produksi dilakukan untuk mencapai tujuan tertentu yaitu:

1. Efektif dan efisien dalam menggunakan bahan baku produksi

2. Tepat jumlah dan tepat waktu dalam melaksanakan proses produksi
3. Memperoleh atau meningkatkan keuntungan

4. Meningkatkan kapasitas produksi sehingga tercapai produktivitas yang tinggi

5. Meminimasi pemborosan seperti overproduction

Rencana produksi dapat dilakukan dengan implementasi peramalan produksi terhadap permintaan dari pelanggan [2]. Peramalan produksi merupakan salah satu kegiatan yang dilakukan industri untuk menentukan jumlah produk yang harus dihasilkan. Jumlah produk yang dihasilkan harus sesuai dengan permintaan pelanggan maka disebut dengan ramalan produksi[2]. Oleh karena itu, selain penyampaian materi rencana produksi, tim pengabdi juga memberikan materi mengenai peramalan produksi.

Materi ramalan produksi yang diberikan yaitu metode regresi linear. Metode peramalan dengan regresi linear merupakan salah satu metode yang paling sederhana dan mudah dipahami. Metode regresi linear menggunakan persamaan sebagai berikut [2]:

$\mathrm{Y}=\mathrm{a}+\mathrm{bt}$

Dimana:

$\mathrm{Y}=$ Hasil Peramalan

$\mathrm{a}=$ konstanta linear

$\mathrm{b}=$ koefisien linear

$\mathrm{t}=$ periode waktu

Berdasarkan hasil kegiatan yang telah dilakukan berikut ini penjelasan dari setiap dokumentasi yang ada. Gambar 1 menunjukkan pemilik mitra keripik 
yaitu Ibu Hafsah. Gambar 2 menunjukkan pemilik mitra kue bawang yaitu ibu As. Gambar 3 merupakan keripik yang siap dijual oleh ibu Hafsah untuk dititipkan di warung, kantin dan toko.

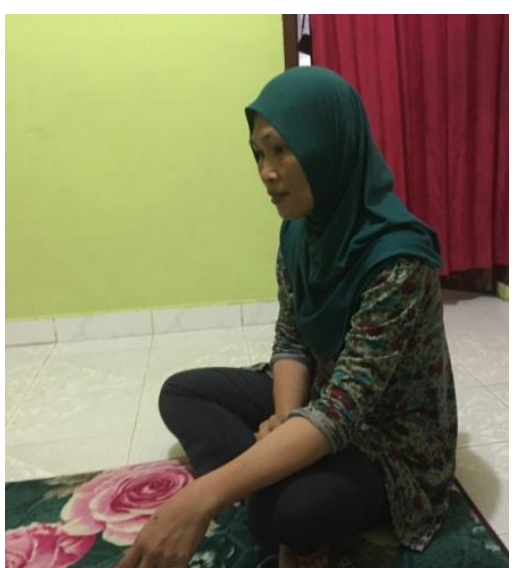

Gambar 1. Mitra Keripik Ibu Hafsah

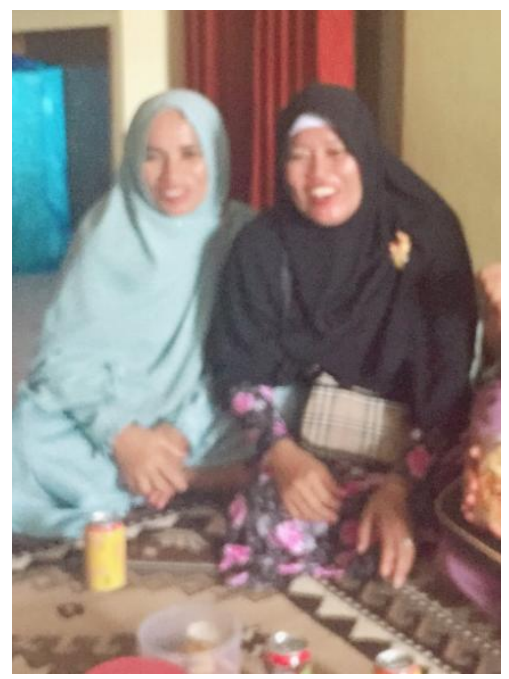

Gambar 2. Mitra Kue Bawang Ibu As

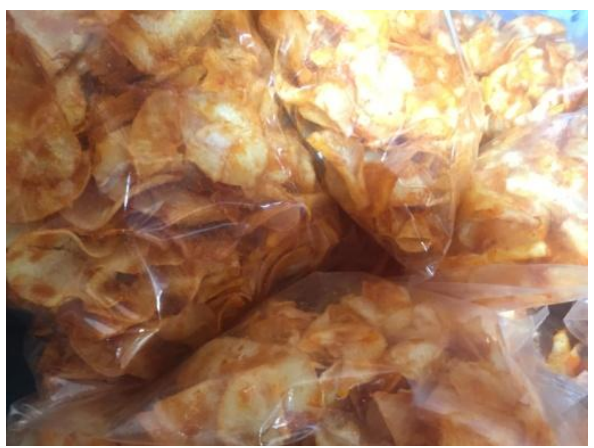

Gambar 3. Produk Keripik

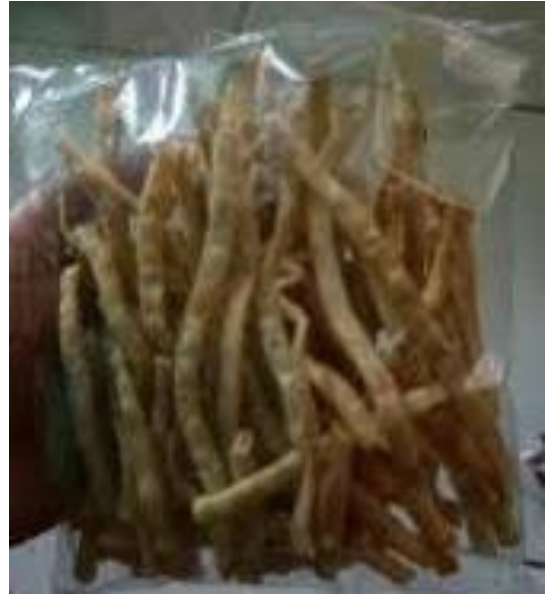

Gambar 4. Produk Kue Bawang

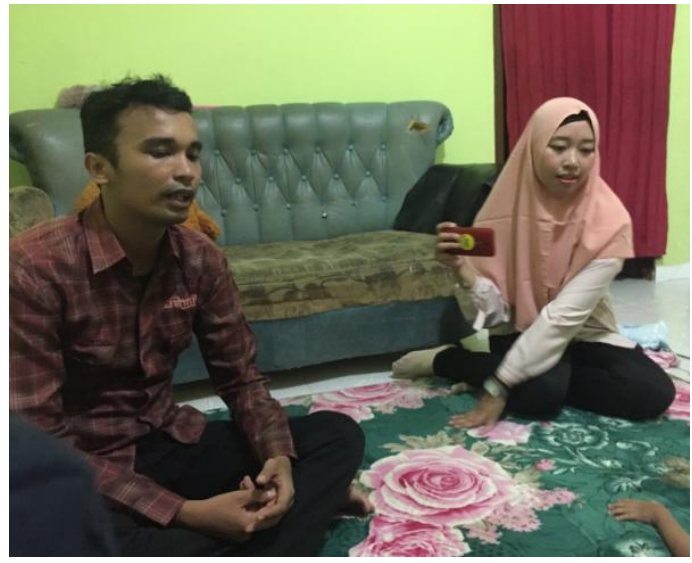

Gambar 5. Kegiatan Pengabdian 1

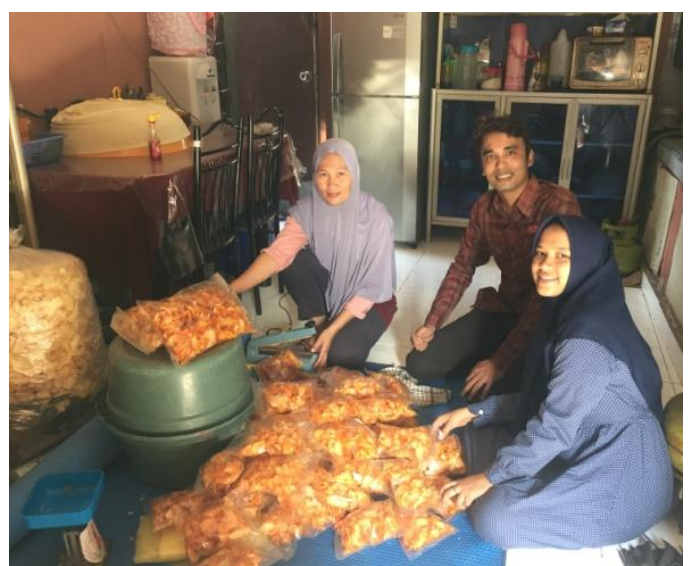

Gambar 6. Kegiatan Pengabdian 2

Sedangkan Gambar 4 menunjukkan kue bawang yang siap dikemas untuk dipasarkan nantinya. Gambar 5 menunjukkan kegiatan pengabdian pertama yaitu survei dan penyampaian maksud dari kegiatan pengabdian kepada mitra. Sedangkan Gambar 6 menunjukkan kegiatan pengabdian 
pertama. Adapun kegiatan pengabdian pertama adalah menjelaskan materi rencana produksi.

Kegiatan pemaparan materi rencana produksi juga dijelaskan materi mengenai peramalan produksi kepada kedua mitra. Materi ini penting bagi kedua mitra agar dapat meningkatkan produktivitasnya.

Tabel 1. Hasil Pencapaian Mitra

\begin{tabular}{|c|c|c|c|}
\hline \multirow{2}{*}{ Mitra } & $\begin{array}{c}\text { Produksi } \\
\text { Bulanan } \\
\text { (Bks) }\end{array}$ & $\begin{array}{c}\text { Produksi } \\
\text { Bulanan } \\
\text { (Bks) }\end{array}$ & Hasil \\
\cline { 2 - 3 } Sebelum & Sesudah & \\
\hline Keripik & 40 & 75 & $\begin{array}{c}\text { Peningkatan } \\
\text { Produksi }\end{array}$ \\
\hline $\begin{array}{c}\text { Kue } \\
\text { Bawang }\end{array}$ & 30 & 50 & $\begin{array}{c}\text { Peningkatan } \\
\text { Produksi }\end{array}$ \\
\hline
\end{tabular}

Hal ini sesuai dengan penelitian [3], yaitu untuk memenuhi permintaan yang berfluktuasi, suatu unit usaha haru menetapkan rencana produksi agar dapat terus memenuhi permintaan pelanggan. Oleh karena itu, URT Keripik dan Kue Bawang dapat memenuhi permintaan baik untuk pesanan maupun untuk penitipan.

\section{KESIMPULAN}

Kesimpulan harus mengindikasi secara jelas hasil-hasil yang diperoleh, kelebihan dan kekurangannya, serta kemungkinan pengembangan selanjutnya. Adapun kesimpulan dari hasil kegiatan pengabdian ini adalah sebagai berikut:

a. URT Keripik dan URT Kue Bawang hanya memproduksi jumlah yang sama setiap produk tanpa adanya rencana produksi dan estimasi penjualan.

b. Berdasarkan hasil pelaksanaan pengabdian, URT Keripik dan URT Kue Bawang mulai menerapkan perencanaan produksi dengan konsep peramalan.

c. Berdasarkan hasil implementasi tersebut, mitra keripik dan mitra kue bawang dapat meminimasi pemborosan overproduction dan menjadwalkan produksi secara efektif dan efisien.

\section{SARAN}

Adapun saran dari kegiatan pengabdian ini untuk lebih optimal lagi dalam membantu meningkatkan kapasitas usaha rumah tangga keripik dan kue bawang yaitu:

a. Kegiatan pengabdian berikutnya dilakukan untuk membina dan mendampingi mitra dalam meningkatkan kualitas produk baik secara organoleptik maupun dari segi packaging.

b. Kegiatan pengabdian berikutnya dilakukan untuk membina dan mendampingi mitra dalam meningkatkan pemsaran produk baik melalui direct selling (toko, stand, mouth to mouth) maupun secara online (website, aplikasi online).

c. Kegiatan pengabdian berikutnya dilakukan untuk membina dan mendampingi mitra dalam peningkatan produksi dengan menggunakan teknologi tepat guna, baik itu menggunakan teknologi produksi yang sudah ada saat ini maupun membimbing dalam mengembangkan teknologi produksi sesuai dengan kebutuhan mitra. 


\section{UCAPAN TERIMA KASIH}

Penulis mengucapkan terima kasih kepada Universitas Putera Batam dan Lembaga Penelitian dan Pengabdian Masyarakat Universitas Putera Batam yang telah memberi dukungan secara finansial dalam dana hibah internal Pengabdian Kepada Masyarakat untuk Skema Pembinaan Kemitraan Masyarakat 2018-2019 terhadap pengabdian ini.

\section{DAFTAR PUSTAKA}

[1]Al-Amin, Mukayat, Maro'ah, Sari, 2017, Geliat Usaha Mikro Ibu-Ibu Rumah Tangga dari Keluarga Miskin Pembutan Abon Bandeng dan Kecap di Gunung Anyar Kota Surabaya, Aksiologiya, vol 1, no 2 hal 126-134.

[2] Ginting, Rosnani, 2012, Sistem Produksi, Vol. 1, Ed.2, Graha Ilmu, Jakarta.

[2] Sirait, M. E., Sinulingga, S., Ishak, Aulia. 2013. Perencanaan Kebutuhan Kapasitas (Rough Cut Capacity Planning) Industri Pengolahan Peralatan Rumah Tangga di PT X. e-Jurnal Teknik Industri FT USU. Vol. 2, No.2, pp. 28-34. Universitas Sumatera Utara: Medan.. 